\title{
Effect of Implementation Problem Posing Method and Problem Solving Methods of Creative Thinking Ability Students
}

\author{
Nurul Haeriyah Ridwan, Agus Rahayu \\ Sekolah Pascasarjana, Universitas Pendidikan Indonesia \\ Setiabudhi St No. 229 Bandung \\ email: haeriyahridwan@student.upi.edu
}

\begin{abstract}
His study aims to Determine the effect of the problem posing method and problem solving method to students' ability to think creatively. issues that are the focus of this research is due to the low level of students' ability to think creatively. Both models of learning are equally focused on solving the problem, the difference between the two is, in Problem Solving learning models, the issue raised Came from teachers, while on Problem Posing learning models, the issue raised Came from students Themselves. This research is a quasi-experimental research design noneequivalent control group design. The study population was all students of class XII IIS SMA Negeri 1 Lembang and a sample of 113 people. Data analysis using SPSS version 21 with statistical hypothesis testing through paramentric. The average difference test (paired sample test). Results of the study found There are significant differences increase of creative thinking ability of students' use of the methods of problem posing with problem solving.
\end{abstract}

Keywords: Creative Thinking, Problem Posing Method, Problem Solving Method

\section{I. . INTRODUCTION}

In order to meet the golden generation of Indonesia in 2015. Indonesia circuiting the technological developments that increasingly unstoppable. The development is inseparable from the development economics. has been presented that one of the objectives of economic subjects is to equip learners with the ability to think logically, analytical, systematic, critical, and creative, and the ability to cooperate. Based on these objectives seen that the ability to think creatively is one important point in the implementation of economic learning in school.

Phenomenon in the field so far has shown that the learning process is still a lot of problems. From interviews with educators, in the process of studying economics in class XI SMAN I Lembang has weaknesses that affect the ability to think creatively economy learners. Based on the results of prior research, researchers get the test results of students of teachers of economics, it turns out these results indicate a value less than satisfactory. The learning process is less varied to make students bored in the following study, have an impact on the lack of creative ability of students in the following study, has resulted in a lack of motivation in participating in the learning economy which results in students being lazy so the effect on thinking skills of learners towards learning materials teaching that must be mastered. Problem-solving skills close relation to creative thinking Kiesswetter (in Hafitria, 2015, p. 3) argues that in his experience, flexible thinking which is a component in creative thinking ability is one of the most important, perhaps even the main one, which must be owned by a good problem-solver.

Besides learning method problem posing as a method of filing of the problems associated with the ability of teachers to motivate students through the formulation of challenging situations so that students can ask questions that can be solved economy and result in the increased ability to solve problems. This study uses problem solving as a method to enhance the students' ability to think creatively .. Curriculum 2013 is a form of intervention (intervention) The Government of Indonesia in improving the quality of human resources through various programs or school activities in place since 2013

The learning model Problem Solving and Problem Posing are two among the many models of learning that involves the activities of students as well as their creativity in the learning process. Problem Solving learning model has an idea as a learning process that requires students to solve problems, which can be made-up by the educator or the real fact that in the environment then solved in the classroom, in various ways and techniques. Both models of learning are equally focused on problem solving, students are encouraged to be active so that the information not only from teachers, but students are also required to construct their own knowledge with their new or update their previous knowledge

From some of the above, the researchers are encouraged to create learning that is able to develop models of learning problem solving. To that end, the researchers used a model of learning problem posing and problem solving, because both the learning model is the submission of the problem and solving the problem. From the second model of learning proficiency level, the researchers wanted to prove learning model which is better applied in class XII SMA Negeri 1 school year 2015/2016. Based on these descriptions authors conducted a study entitled "Effect of Filing Application Method Problems and Troubleshooting Methods Of Creative 


\section{$\therefore$ ATLANTIS PRESS}

Thinking Ability Students (Quasi-Experimental Study On Economic Subjects in SMA Negeri 1 Lembang)".

\section{METHODOLOGY}

The methodology used in this research is a quasiexperimental research or "quasi-experiment consisting of two groups of research is experimental class were studying with learning methods Problem Posing and Problem Solving and grade control with type design in this study is the design Nonequivalent (pretest and posttest) Control group design. Data analysis using SPSS version 21 with statistical hypothesis testing through paramentric.

\section{RESULTS AND DISCUSSION}

This research was conducted in SMA Negeri 1 Lembang class XI second semester of the academic year 2015-2016, using three classes consisting of two experimental class and first class control. For the experimental class, the first class given learning method of filing problem (Problem Posing) and the second class given learning method solving (Problem Solving). As for the class get control of learning methods konvensionalDari research has been carried out, each of the students in the experimental group were asked to provide feedback on teaching methods that have been done. Here is presented a response to the students' learning method that has been done.

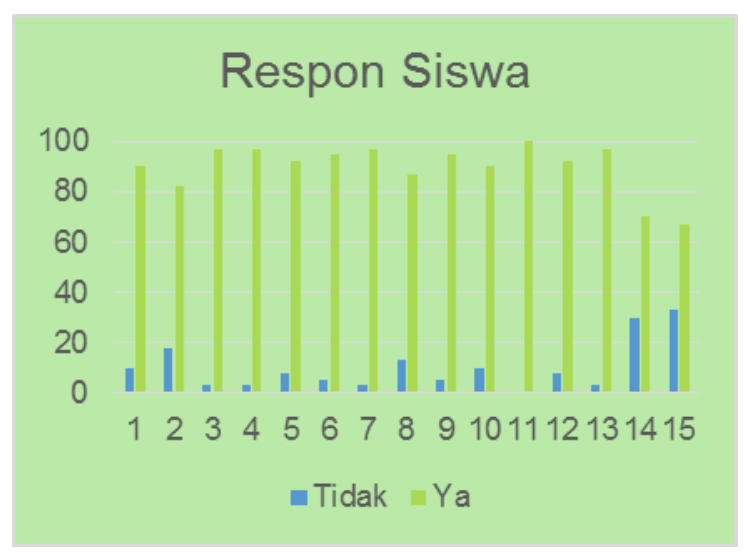

Fig. 1. Response Against Student Learning Problem Posing Method

In Figure 1 students' response to the learning method of filing problem (Problem Posing) overall giving positive feedback. This is evidenced by the number of students who answer "yes" to a question asked teachers.

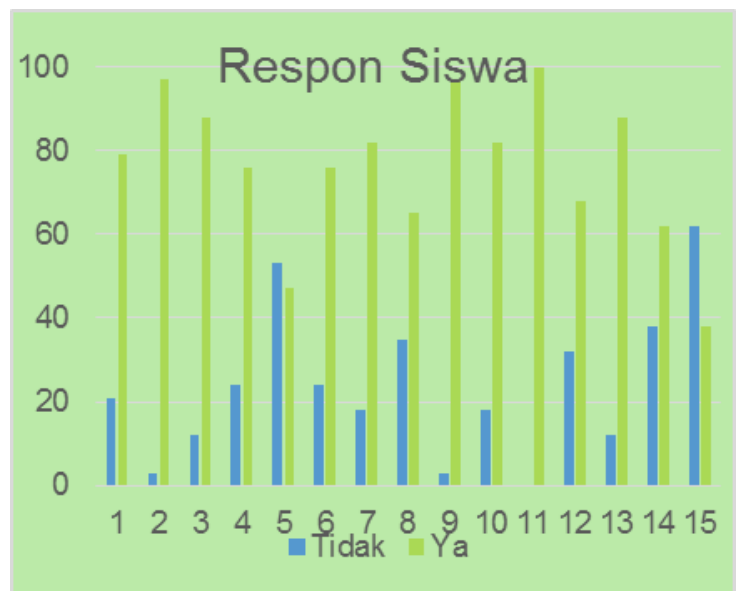

Fig. 2. Response Against Student Learning Problem solving Method

In Figure 2, the overall response of the students were given a positive terhada this method. Evidenced by the number of students who responded by answering "yes". At each question item.

Table 1 and Figure 3 shows the results of pretest and posttest creative thinking ability of students who use the method of filing problem (Problem Posing). From the table looks average pretest at 12.21, and after being given treatment increased by 0.62 which was categorized into 18.65 .

TABLE I. RESUlTS PRETEST AND POSTTEST IN THE EXPERIMENT Class Method Using Filing Problems (Problem Posing) AND Class CONTROLS

\begin{tabular}{|c|c|c|c|}
\hline \multirow{2}{*}{ Students } & \multicolumn{3}{|c|}{ Mean } \\
\hline & Pretest & Postest & N-Gain \\
\hline 39 & 12.21 & 18.65 & 0.62 \\
\hline 40 & 16.97 & 16.24 & 0.53 \\
\hline
\end{tabular}

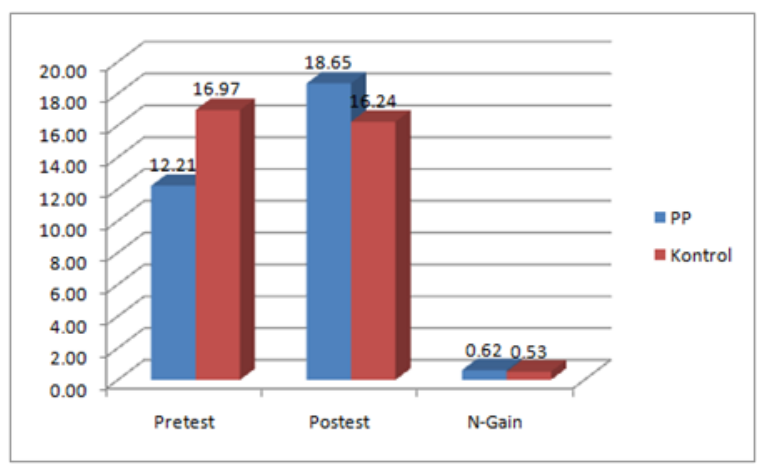

Fig. 3. Results Pretest and Posttest In The Experiment Class Method Using Filing Problems (Problem Posing) and Class Controls

Table 2 and Figure 4 shows the results of pretest and posttest creative thinking ability of students to use problemsolving methods (problem solving). The table shows the average pretest at 15.15 , and after being given treatment which increased by 0.15 lower to 16.65 uncategorized. 
TABLE II. RESUlts PRETEST AND PostTest In ITS Class EXPERIMENTS USING TROUBLESHOOTING METHODS (PROBLEM SOLVING) AND CLASS CONTROLS

\begin{tabular}{llll}
\hline \multirow{2}{*}{ Students } & Pretest & Postest & N-Gain \\
\hline 34 & 15.15 & 16.65 & 0.15 \\
40 & 16.97 & 16.24 & 0.53 \\
\hline
\end{tabular}

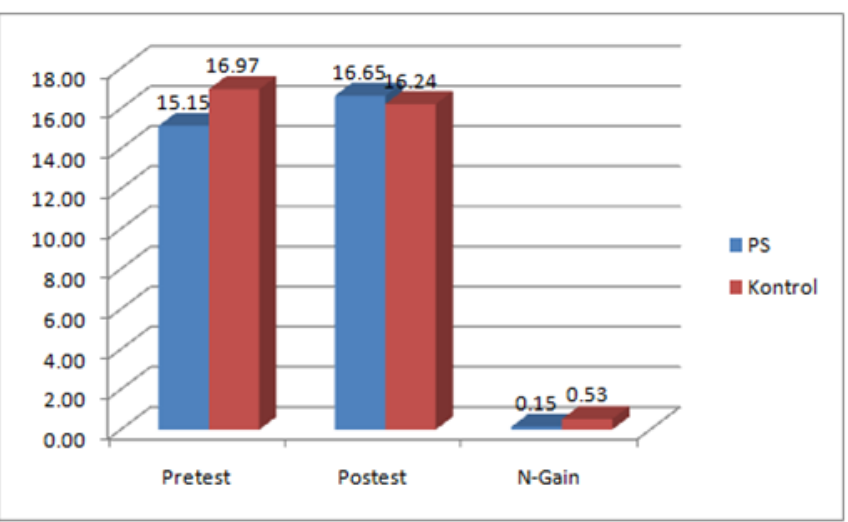

Fig. 4. Results Pretest and Posttest In Its Class Experiments Using

Troubleshooting Methods (Problem Solving) and Class Controls

Testing the hypothesis in this study was conducted to determine whether the hypothesis is accepted or rejected. In this study there were five hypothesis testing that will be proposed, namely:

\section{1) First Hypothesis Testing}

The first hypothesis in this study there is an increased ability of creative thinking of students who use the method of submission of an issue (problem posing) before and after treatment (treatment). The results of data processing for the test can be seen in the following table:

TABLE III. FIRST HyPOTHESIS TEST RESUlTS

\begin{tabular}{rlrlll}
\hline Group & Students & Mean & Correlate & t-hitung & p-value \\
\hline Pretest PP & 39 & 12.44 & & & \\
Postest PP & 39 & 18.67 & & & 0.09 \\
\hline
\end{tabular}

From Table 3 above shows that the average value of creative thinking ability of students in the group filing the problem (problem posing) before being given treatment at 12:44. Lower when compared with the ability to think creatively after a given treatment amounting to 18.67. This shows that the learning method of filing problems (problem posing) can improve students' ability to think creatively. From the results of hypothesis testing, the value of t-count equal to -10.893 with a significance value of $0.000<0.05$. In accordance with the criteria of testing the hypothesis that $\mathrm{H} 0$ rejected and $\mathrm{Ha}$ accepted, meaning that there are significant differences creative thinking ability of students to use learning methods filings problems (problem posing) before and after treatment (treatment).

\section{2) Second Hypothesis Testing}

The second hypothesis in this study there is an increase in creative thinking ability of students to use problemsolving methods (problem solving) before and after treatment (treatment). The results of data processing for the test can be seen in the following table:

TABLE IV. SECOND HYPOTHESIS TEST RESULts

\begin{tabular}{llllll}
\hline Group & Students & Mean & Correlate & t-hitung & $\begin{array}{c}\text { p- } \\
\text { value }\end{array}$ \\
\hline Pretest PS & 34 & 15.15 & 0.12 & -3.339 & 0.002 \\
Postest PS & 34 & 16.65 & & & \\
\hline
\end{tabular}

From Table 4 above shows that the average value of creative thinking ability of students in group problem solving (problem solving) before being given treatment equal to 15,15 . Lower when compared with the ability to think creatively after a given treatment 16.65 . This shows that the learning method problem solving (problem solving) can improve students' ability to think creatively. From the results of hypothesis testing, the value of t-count of -3.399 with a significance value of $0.002<0.05$. In accordance with the criteria of testing the hypothesis that $\mathrm{HO}$ rejected and $\mathrm{Ha}$ accepted, meaning that there are significant differences creative thinking ability of students to use learning methods solving (problem solving) before and after treatment (treatment).

\section{3) 3. Third Hypothesis Testing}

The third hypothesis in this study there is an increased ability of creative thinking of students who use the method of submission of an issue (problem posing) and learning methods lecture after treatment (treatment). The results of data processing for the test can be seen in the following table:

TABLE V. ThIRD HyPOTHESIS TEST RESUlts

\begin{tabular}{lllll}
\hline \multicolumn{1}{c}{ Group } & Students & Mean & t-hitung p-value \\
\hline N-Gain & 40 & -0.53 & -9.767 & 0.000 \\
Kontrol & & 6.23 & & \\
N-Gain PP & 39 & & & \\
\hline
\end{tabular}

From Table 5 above shows that the average value increase of creative thinking ability of students in the group filing the problem (problem posing) after being given treatment amounting to 6.23. Higher when compared to the increase in the ability to think creatively lecture after lecture given treatment using the method of -0.53 . This shows that the learning method of filing problems (problem posing) higher in enhancing the ability of creative thinking of students compared with the lecture method. From the results 
of hypothesis testing, the value of t-count of -9.767 with a significance value of $0.000<0.05$. In accordance with the criteria of testing the hypothesis that $\mathrm{HO}$ rejected and $\mathrm{Ha}$ accepted, meaning that there are significant differences increase creative thinking ability of students to use learning methods filings problems (problem posing) with improved teaching methods lecture after treatment (treatment).

\section{4) Fourth Hypothesis Testing}

The fourth hypothesis in this study there is an increase in creative thinking ability of students to use problem-solving methods (problem solving) and learning methods lecture after treatment (treatment). The results of data processing for the test can be seen in the following table:

TABLE VI. FOURTH HYPOTHESIS TEST RESUlTS

\begin{tabular}{lllcc}
\hline \multicolumn{1}{c}{ Group } & Students & Mean & $\begin{array}{c}\text { t- } \\
\text { hitung }\end{array}$ & $\begin{array}{c}\text { p- } \\
\text { value }\end{array}$ \\
\hline $\begin{array}{l}\text { N-Gain } \\
\text { Kontrol }\end{array}$ & 40 & -0.53 & & \\
N-Gain PS & 34 & 4.44 & & \\
\hline
\end{tabular}

From Table 6 above shows that the average value increase of creative thinking ability of students in group problem solving (problem solving) after being given treatment amounting to 4.44. Higher when compared to the increase in the ability to think creatively lecture after lecture given treatment using the method of -0.53 . This shows that the learning method problem solving (problem solving) higher in enhancing the ability of creative thinking of students compared with the lecture method. From the results of hypothesis testing, the value of t-count of -8.175 with a significance value of $0.000<0.05$. In accordance with the criteria of testing the hypothesis that $\mathrm{HO}$ rejected and $\mathrm{Ha}$ accepted, meaning that there are significant differences increase creative thinking ability of students to use learning methods solving (problem solving) with improved teaching methods lecture after treatment (treatment).

\section{5) Fifth Hypothesis Testing}

The third hypothesis in this study there is an increased ability of creative thinking of students who use the method of filing problems (problem solving) and learning methods solving (problem solving) after treatment (treatment). The results of data processing for the test can be seen in the following table:

TABLE VII. FIFTH HYPOTHESIS TEST RESUlTS

\begin{tabular}{rllll}
\hline Group & Students & Mean & t-hitung & p-value \\
\hline N-Gain PP & 39 & 6.23 & 2.367 & 0.021 \\
N-Gain PS & 34 & 4.44 & & \\
\hline
\end{tabular}

From Table 7 above shows that the average value increase of creative thinking ability of students in the group filing the problem (problem posing) after being given treatment amounting to 6.23. Higher when compared to the increase in the ability to think creatively solving problems (problem solving) after being given treatment amounting to 4.44. This shows that the learning method of filing problems (problem posing) higher in enhancing the ability of creative thinking of students compared with the method of problem solving (problem solving). From the results of hypothesis testing, the value of t-count equal to 2,367 with significance value of $0.021<0.05$. In accordance with the criteria of testing the hypothesis that $\mathrm{HO}$ rejected and $\mathrm{Ha}$ accepted, meaning that there are significant differences increase creative thinking ability of students to use learning methods filings problems (problem posing) with improved methods of teaching problem solving (problem solving) after treatment (treatment).

Studies associated with the process is inseparable from the use of methods studies one of a learning method that can be used in the implementation of Curriculum 2013 is a learning method of filing problems (problem posing) and learning methods fixers (problem solving). Based on research both methods are proven to improve students' creative abilities. As it is expressed by Momon Sudarman (2013, Pg. 48) that the problem-solving mode based learning (problem solving, based, learning) is part of conditioning effort among students for creative and critical thinking bias.

The learning method of filing problems (problem posing) and learning methods solving (problem solving) can be used to improve the ability to think creatively students in the learning economy. Learning scenarios in teaching methods should be applied systematically for encouraging students to think systematically in problem solving alternatives.

\section{CONCLUSION}

The results of this study concluded that the application of the learning method of filing problem (Problem Posing) and learning methods solving (problem solving) is a learning method that can be used to enhance the students' ability to think creatively.

In particular, based on the formula of the problem and the hypothesis of the proposed research and the results of data analysis and discussion presented, it can be concluded as follows:

1) There are significant differences increase creative thinking ability of students who uses the method of filing problem.

2) There are significant differences increase creative thinking ability of students' use of problem-solving methods.

3) There are significant differences increase students' ability to think creatively that uses the methods of filing a problem with the lecture method.

4) There are significant differences increase creative thinking ability of students' use of problem-solving method (method.

5) There are significant differences increase students' ability to think creatively that uses the methods of filing with the problem solving methods. 


\section{REFERENCES}

[1] Filsaime, Dennis K, (2008). Menguak Rahasia Berpikir Kritis dan Kreatif. Jakarta: Prestasi Pustakaraya.

[2] Suryono dan Hariyanto, (2014). Belajar dan Pengajaran: Teori dan Konsep Dasar. Bandung : PT Remaja Rosdakarya.

[3] Suryosubroto. B, (2013). Proses Belajar Mengajar di Sekolah. Bandung: Rineka Cipta.

[4] Huda, Miftahul, (2014). Model-model Pengajaran dan Pembelajaran. Yogyakarta : Pustaka Pelajar.

[5] Adji, Wahyu, (2007). Ekonomi Untuk SMA/MA Kelas X. Jakarta: Erlangga

[6] Ahmadi, Abu Joko Prasetya. (1997). SBM Strategi Belajar Mengajar Untuk Fakultas Tarbiyah KOmponen MKDK. Bandung : Pustaka Setia

[7] Amir, Taufiq. (2010). Inovasi Pendidikan Melalui Problem Based Learning Bagaimana Pendidik Memberdayakan Pembelajaran di Era pengetauan. Jakarta: Kencana.

[8] Arikunto, Suharsimi. (2010). Prosedur Penelitian Suatu Pendekatan dan Praktek. Jakarta: Rineka Cipta.

[9] Budiman Agung. (2015). Peningkatan Kemampuan Pemecahan Masalah Berpikir Kreatif Matematis dan Habits of Mind Siswa SMA Melalui Pendekatan Creative Problem Solving

[10] Daswa. (2013). Penerapan Model Pembelajaran Sinektik untuk Meningkatkan Kemampuan Berpikir Kreatif dan Komunikasi Matematis Siswa Madrasah Tsanawiyah. Bandung : Universitas Pendidikan Indonesia.

[11] Djamarah, Syaiful Bahri dan Aswan Zain (2002). Strategi Belajara Mengajar. Yogyakarta: Liberty.

[12] Fisher, Ribert and Mary Williams. (2004). Unlocking Creativity. British Library Cataloguing in Publication Data.

[13] Gulo, W. (2002). Strategi Belajar Mengajar. Jakarta: Grasindo.

[14] Hafitna Sitti. (2015) Meningkatkan Kemampuan Pemecahan Masalah dan Berfikir Kreatif Matematika Siswa SMP dengan Menggunakan Pendekatan Pembelajaran Creative Problem Solving. Bandung : Universitas Pendidikan Indonesia.

[15] Haryanto Dwi. (2013). Penerapan Model Search, Create, and Share dengan Pendekatan Problem Posing untuk Meningkatkan kemampuan Penalaran dan Komunikasi Matematis Siswa SMP. Bandung : Universitas Pendidikan Indonesia.

[16] Helmut R lang, and David N. Evans. (2006). Models, Strategies, and Methods For Effective Teaching. Pearson Education.

[17] Jack R. Frankel dan Norman E. Wallen (1993). How To Design And Evaluate Research in Education Second Edition. The Mc.Graw Hills Companies.

[18] Jeffrey, at all. (2004). Teaching creatively and teaching for creativity: distinctions and relationships. The Open University's repository of research publicationsand other research outputs.

[19] Kimberlin, Carole. L dan Winterstein Almut. G. (2008). Validity and reliability of measurement instruments. Reserch Fundamenta. Universitas of Florida.

[20] Kusnendi. (2013). Skala Pengukuran dan Teknik Analisis Data Dalam Penelitian Non Eksperimen dan Eksperimen. Bandung: Universitas Pendidikan Indonesia.

[21] Lorin W. Anderson dan David R. Krathwohl. (2010) Kerangka Landasan Untuk Pembelajaran, pengajaran, dan Asesmen, Yogyakarta: Pustaka Pelajaran.

[22] Majid, Abdul. (2013). Strategi Pembelajaran. Bandung: Rosdakarya.

[23] Mulyasa, Abdul. (2013). Pengembangan dan Immplementasi Kurikulum 2013: Bandung: Rosda Karya.

[24] Paul Eggen dan Don Kauchak. (2012). Strategi dan Model Pembelajaran Mengajarkan Konten dan Keterampilan Berpikir Edisi Keenam. Jakarta: PT. Indeks Permata Puri Media.

[25] Richard I. Arends. (2007). Learning To Teach Belajar Untuk Mengajar. Edisi Ketujuh. Yogyakarta: Pustaka Pelajar.

[26] Riduwan. (2012). Pengantar Statistika. Bandung : Alfabeta.
[27] Rusman. (2010). Model-Model Pembelajaran Berorientasi Standar Proses Pendidikan. Jakarta: Kencana.

[28] S, Alam. (2006). Ekonomi Untuk SMA dan MA Kelas X. Jakarta: ESIS

[29] Safari. (2008). Analisis Butir Soal. Jakarta: Asosiasi Pengawas Sekolah Indonesia, Departemen Pendidikan Nasional.

[30] Sanjaya, Wina. (2011). Strategi Pembelajaran Beriontasi Standar Proses Pendidikan. Jakarta: Kencana.

[31] Silver, Edward a. (2008). On Mathematical Problem Posing Publishing Association, Vancouver. British Columbia, Canada.

[32] Siregar. Eveline dan Hartini Nara. (2010). Teori Belajar dan Pembelajaran. Bogor:: Ghalia Indonesia.

[33] Siswono, Tatag Yuli (2005). Upaya Meningkatkan Kemampuan Berpikir Kreatif Siswa Melalui Pengajuan Masalah. Yogjakarta : Universitas Negeri Yogyakarta.

[34] Solihat, Ai Nur. (2014). Studi Komperatif penggunaan Metode Pembelajaran Berbasis Masalah (Problem Based Learning) dan Metode Pembelajaran Pemecahan Masalah (problem Solving) dalam Meningkatkan Kemampuan Berpikir Kreatif Siswa. Bandung : Universitas Pendidikan Indonesia.

[35] Sri Hastuti Noer. (2011). Kemapuan Berpikir Kreatif Matimatis dan Pembelajaran Matimatika. Bandung : Universitas Pendidikan Indonesia

[36] Sudarman, Momon. (2013). Mengembangkan Keterampilan Berpikir Kreatif. Jakarta: PT. Raja Grafindo Persada.

[37] Sugianto. (2012). Mengolah Data Bisnis Dengan SPSS 20. Jakarta:Elex Media Komputiondo.

[38] Sugiyono. (2012). Metode Penelitian Kuantitatif, Kualitatif dan $R \& D$. Bandung: Alfabeta.

[39] Suyono, dan Hariyanto. (2011). Belajar dan Pembelajaran Teori dan Konsep Dasar, Bandung: Rosdakarya.

[40] Torrance, E. Paul. (1995). Why Fly A Philosophy of Creativity. Ablex Publishing Corperation.

[41] Yamin, Martinis. (2012). Desain Baru Pembelajaran Konstruktivistik: Jakarta: Referensi.

[42] Hamzah \& Kimberly G. Griffith. Fostering. Problem Solving \& Creative Thinking in the Classroom: Cultivating a Creative Mind. Tersedia [online]: http:/www.nationalforum.com/

[43] Kementrian Pendidikan dan Kebudayaan (November 2012). Pengembangan Kurikulum 2013. Tersedia [Online] http:/www.kemdikbud.go.id

[44] KOMPAS ONLINE. Tersedia [Online]: http:/www.kompas.com

[45] Kyung Hee Kim. The Creativity Crisis: The Decrease in Creative Thinking Scores on the Torrance Tests of Creative Thinking. Tersedia [online]: $\quad$ http:/kim wmwikis.net/file/view/kim_2011_Creativity_crisis.pdf

[46] Matt Baker, Rick Rudd, Carol Pomeroy, Relationships Between Critical and Creative Thinking. Tesedia [Online]: http:/www.bookza.org

[47] Noer. Sri. Hastuti. Kemampuan Berpikir Kreatif Matimatis dan Pembelajaran Matimatika Berbasis Masalah Open-Ended. Tersedia [Online]: http:/www.ejournal.unsri.ac.id

[48] Siswono, Tatang Yuli Eko. Upaya Meningkatkan Kemampuan Berpikir Kreatif Siswa Melalui Pengajuan Masalah. Tersedia [Online]: 